\title{
Justification of the Tortious Legislation by the RF Constitution Requirements
}

\author{
Valentina I. Plokhova* \\ Altai State University \\ 81 Krasnoarmeiskii, Barnaul, 656031, Russia
}

Received 07.08.2014, received in revised form 17.10.2014, accepted 22.11.2014

Constitutional requirements to form and content of the law restricting human rights and freedoms, including the law of torts, are referred to and shortly characterized in the article. Characteristic features of the legal law, constituting the notions of the law supremacy, its correlation to formal and substantial requirements to the law are dwelt upon.

Keywords: legal law, law supremacy, predictability, the degree of importance, content, form.

Research area: law.

The relevance of the topic is determined by the changes in the Criminal Code of the Russian Federation which are often spontaneous and unsubstantiated and both reinforcing criminal repression and softening it. This results in violation of the citizens' rights and legitimate interests. On October 21, 2014 the Constitutional Court of the Russian Federation considered the case about the constitutionality verification of, for example, Article 159.4 of the Criminal Code of the Russian Federation. It was initiated by the request of the Salekhard municipal court of Yamalo-Nenets Autonomous Okrug. The applicant believes that the contested norm unreasonably provides entrepreneurs and employees of commercial organizations with significant incentives, placing the rest of the citizens in the position of inequality. In his opinion, the sanctions, established by the article, are extremely soft and inadequate towards a social danger of such crimes. In addition, the applicant states that the debatable provision violates the victims' rights, limiting their right to access to justice and indemnification. Basing on this, he considers the norm to be nonconforming to articles 19 and 52 of the Constitution of the Russian Federation.

Article 15 of the Constitution of the Russian Federation secures the superior legal force, direct effect of the Constitution of the Russian Federation, and its application on the territory of the country. According to it, the decisions of the Constitutional Court and the Plenum of the Supreme Court of the Russian Federation, generally recognized principles and norms of the international law, international treaties of the Russian Federation, interpretation of the ECHR convention provisions are included in the Russian legal system. Laws and other legal acts, adopted in the Russian Federation, must not contradict the Constitution of the Russian Federation.

(C) Siberian Federal University. All rights reserved

* Corresponding author E-mail address: VPlohova@yandex.ru 
Thus, constitutional and international norms, generally recognized principles of theinternational law, their interpretation by the Constitutional Court of the Russian Federation, ECHR must be transformed into the Conception of the criminal law development, taken into consideration at criminalization, decriminalization of acts (both full and partial), penalization (depenalization), securing evidences of a crime, its interpretation, application of the criminal and legal norm.

Constitutional and international norms provide the possibility of governmental interference in the citizens' rights under the law. Part 3 of Article 55 of the Constitution of the Russian Federation states the federal law under which the restrictions of human rights may apply. Furthermore, according to legal propositions of the Constitutional Court of the Russian Federation, as the subjects of the Russian Federation have the right to restrict, for example, ownership, establishing regional taxes and fees, the grounds for restricting human rights and freedoms may be provided by an international treaty. It is due to the fact that the Constitutional Court stipulates that the laws of the subjects of the Russian Federation on taxes and dues as well as international treaties are fully subject to the provisions of Article 55 (Part 3) of the Constitution of the Russian Federation. Yet the restriction of rights under the law of the subject of the Russian Federation is legal only if the possibility of restricting the rights by the laws of the subjects of the Russian Federation is provided for in the Federal Law.

The Constitution of the Russian Federation, ECHR impose certain requirements on the form (legislative technique, procedure of its adoption) and maintenance (validity, proportionality) of law, international treaty. In legal literature they are conventionally divided into formal and material.

The international law, the European and Constitutional Courts' practice, the constitutionalists and legal theorists state the following requirements to the form of the law restricting human rights and fundamental freedoms. The law must be a) available, b) specific, c) stable, and d) predictable. It should be noted that in some cases some of the requirements are applied to by ECHR and the Constitutional Court of the Russian Federation as a final decision on a particular case (certainty), in other cases - as the components of the requirement of predictability, certainty, in the rest cases - as a certain requirement to the law. The main purpose of allocating each of them, as we see it, is to draw a lawmaker's and a law enforcement official's attention to these characteristics of law, taking the peculiarities of the criminal law into account.

A) Availability is regarded by ECHR and the Constitutional Court of the Russian Federation as one of the requirements (or basic requirements, according to the Constitution of the Russian Federation) to the quality of law, restricting the rights. This term is interpreted in the meaning of the law publication for the citizens to have an opportunity to be guided in which legal norms should be applied to a certain case. The requirement to publish the law officially is stated in Part 3 of Article 15 of the Constitution of the Russian Federation, Clause 6 of the Resolution of the Plenum of the Supreme Court of the Russian Federation No. 8 dated October 31, 1995 with subsequent amendments.

In respect of the criminal law ECHR and the Constitutional Court of the Russian Federation repeatedly considered the complaints on the availability of blanket rules constituting the major part of the criminal law. To determine their content it is necessary to know and apply other regulations of different legal force, referring to both regulatory and tort law branches. Such statutory acts should also be published.

B) The criterion of certainty, according to the etymology of this word, means 'well understood, logical, harmonious, clear'. This meaning is 
closer to the term 'clear' which is synonymic to 'certainty'. It is not by chance interpreted in the decisions of the ECHR as 'clear, exact'; in legal literature - in the meaning of 'concreteness of orders' which results from the nature of law in general, the criminal law including. The criminal law contains serious legal restrictions of basic human rights and freedoms, so it is important to clearly observe this requirement to the law for the application of a right to be predictable. However, according to the case-law of the ECHR and the Constitutional Court of the Russian Federation, this does not mean that all the concepts in the laws should be comprehensively dwelt upon in the text of the law itself. The possibility of their interpreting by jurisprudence, when more than one interpretation can be given, is presupposed. In such cases the Supreme Court itself must observe the provisions of the Constitution of the Russian Federation, generally recognized principles and norms of the international law, and treaties while interpreting the norms of the criminal law.

C) Stability of law is immutability of its main provisions at stable socio-political situation in the society. The factors, stipulating and ensuring the stability of law (consistency of its provisions for the interior of the branch of law and for other areas of law, etc.) partially characterize the content of the criminal law.

However, there must be reasonable limits of stability. In case of changing social relations there should be changes in law. This legal position was stated by both the European Court and the Constitutional Court. Thus, the Resolution of the Constitutional Court of the Russian Federation No. 4 dated April 20, 2006 stipulates the reverse side of the principle of stability. "In cases when the measures, provided by the criminal law, cease to comply with social realities, thus leading to weaker protection of constitutionally significant values or, on the contrary, to excessive public enforcement, the legislator is obliged to bring the provisions of the criminal law in line with new social realities on the basis of constitutional principles".

D) Predictability of consequences of governmental interference in human rights and fundamental freedoms means a possibility to anticipate, predict the consequences of such restrictions of rights and, in compliance with the European Court propositions, is intended for a person to be able to foresee the restriction and its consequences with reasonable reliability. In fact, observance of all these formal indicators of the criterion of legality is necessary for a person to be able to foresee the consequences of intervention. Therefore, in legal literature the predictability of consequences of interference is termed as a final formal index of legality of restrictions of human rights.

Availability, certainty, clarity, specificity, stability of law are viewed as means to achieve the goal mentioned - a possibility to anticipate, predict the consequences of restriction of the rights, changes in legal status. The goal and means must agree with each other. The means should be sufficient to achieve the goal. In connection with this it is not accidental that, firstly, some requirements to the form of the law, according to the ECHR and the Constitutional Court of the Russian Federation, can be observed not strictly if the observation of other formal requirements of legality of restrictions ensure the achievement of this goal; secondly, both the European Court and the Constitutional Court consider a specific complaint relating to particular circumstances; thirdly, which is a tactical (interim) and not an ultimate (global) goal as all the formal parameters (conditions) of lawful restrictions of rights (interference) can be observed, but if the law is not justified and the restriction is not commensurate to the legitimate aims it is not necessary in a democratic society. The restriction, necessary in a democratic society, is possible at the observance 
of informative (material) conditions (indicators) of legality of interference with the rights.

In legal literature they suggest both generalized characteristics of substantial constitutional requirements to the law and specifying, detailing ones. It is argued, for example, that the interference with the rights must be based on the substantive law. Many researches and some international documents define this law as complying with the Constitution, universally recognized principles and norms of the international law, the principle of international and domestic law - the supremacy of law.

However, modern regulatory system (neither at the national nor at the international level) and legal literature have not worked out a single concept of the substantive law, the principle of the supremacy of law. This was noted both at the International Symposium "The doctrines of a legal state and the supremacy of law in the modern world", which was held on October 21, 2014 in the Constitutional Court of the Russian Federation, and in the report on the supremacy of law, approved by the Venice Commission at its $86^{\text {th }}$ Plenary Session (Venice, March 25-26, 2011). Meanwhile, according to the speakers, it suggested the most appropriate definition of the supremacy of law and made an attempt to “... provide consensus regarding the necessary components of the supremacy of law and the substantive law, which will be not only formal but also substantive or material ...". The authors of the report consider the following to be the most appropriate in covering the main aspects of the 'supremacy of law' concept: "All persons and authorities in the state, whether public or individual, must be interconnected and have the right to apply the laws, which are publicly accepted, refer (in general) to the future and are publicly executed in the courts" (Clause 36). The report also suggests 6 constituents of the principle of the supremacy of law: 1) legality, including transparent, accountable and democratic process of enactment of law; 2) legal certainty (including availability, stability, clarity and predictability, in the broad meaning of the word); 3) prohibition of arbitrariness; 4) access to justice, ensured by independent and impartial courts, including judicial examination of administrative acts; 5) respect for human rights; 6) non-discrimination and equality before the law. Many of these components of the principle of the superiority of law were also mentioned during the repeated discussions on this topic in the Constitutional Court of the Russian Federation. The report, including the checklist of questions to assess the state of the superiority of law in a particular state regarding the six elements of the superiority of law, briefly describes them and focuses on the details. Thus, the importance to observe the principle of the superiority of law is stated for legality (the first component of the principle of the superiority of law). This means that the law and international agreements should be observed, their violation should be subject to punishment.

Certainty, except for the requirements of accessibility, clarity, accuracy, ensuring predictability of consequences of restrictions of the rights, implies the need for a legal fixation of a state's margin of appreciation in exercising the rights and fundamental freedoms; sequence of the case law, execution of final resolutions of the court; the ban against a retroactive effect of the norms. The following indicators of the observance of the superiority of law in the state are often referred to: "whether there are the state's margins of appreciation in intervening in human rights and fundamental freedoms, whether there are internal norms to ensure the observance of the international law by the state, whether the assessment of legislation (both prior and after its adoption) is carried out on a regular basis, whether the law is applicable, whether there is an independent effective judiciary. 
Therefore, firstly, the principle of the superiority of law is a capacious concept, the principle of governance, the constitutional system of the Russian Federation. Hence it is no coincidence that certain elements of the superiority of law apply to the Constitutional Court of the Russian Federation, the European Court as an independent criterion of legality, certainty, etc., both formal and material criteria of lawful restrictions of human rights. Secondly, despite a certain specification of individual components of the superiority of law their general character is obvious. Thirdly, the emphasis is made on the state's procedural obligations at the interference with the rights and fundamental freedoms, in the fulfillment of laws; on consolidation in the law and administration of safeguards regarding the compliance with generally recognized principles and norms of the international law, observance of human rights and fundamental freedoms.

There is no denying that in different historic periods both in Russia and in the international law the concepts of the substantive law, the superiority of law are interpreted differently. It depends on normative, formal or substantive conception. However, today, regarding legal propositions of the European Court, the Constitutional Court of the Russian Federation, a substantive conception is given a greater emphasis: it is the substantive, well-grounded law but not any law should be the basis of the restrictions of human rights. It was also noted in the report on the superiority of law, approved by the Venice Commission at its $86^{\text {th }}$ Plenary Session (Venice, March 2526, 2011). The following propositions were mentioned in the algorithm of assessment of states regarding their observance of the principle of the superiority of law: a) the law must comply with generally recognized principles and norms of the international law; b) the presence of norms, restricting the state's margin of appreciation in interfering, restricting human rights, the limits of such appreciation; guarantees of their observance prove the necessity of substantial justification of the criminal law. At that, despite the fact that the norms restricting a margin of appreciation in interfering with the rights are stipulated by the international law and international treaties, the importance to observe the limits of restrictions of human rights, subsidiarity of norms of the international law result in the second requirement to the states' legal system - the presence of norms, restricting a margin of appreciation in interfering with the rights, guarantees of their observance.

Hence, as the first indicator of a substantive validity of the law the principle of the superiority of law implies its conformity with generally recognized principles and norms of the international law (termed legal validity); as the second indicator it implies the compliance with the legitimacy at the interference (restriction) with the rights. The tort law, and the Criminal Code of the Russian Federation in particular, base upon the Constitution of the Russian Federation. Thus, the first indicator of the tort law validity can be summarized the following way: its compliance with the Constitution of the Russian Federation, generally recognized principles and norms of the international law, international treaties signed by Russia, the ECHR legal propositions, the Constitutional Court of the Russian Federation (legal validity).

International treaties, the jurisprudence of the Constitutional Court of the Russian Federation, the ECHR suggest and interpret certain indicators of the principle of the superiority of law, including generally recognized principles and norms of the international law, the limits of the restriction of each human right by the norms of different branches, including the tort law. 


\section{References}

1. Lipkina N.N. Legal propositions of the European Court of Human Rights regarding the states' margin of appreciation at interference with rights and fundamental freedoms. Dissertatsiia kandidata iuridicheskikh nauk [Pravovye pozitsii Evropeiskogo Suda po pravam cheloveka otnositel'no svobody usmotreniia gosudarstv pri osushchestvlenii vmeshatel'stva v prava i osnovnye svobody. Ph.D. thesis in Law]. Moscow, 2008. 225 p.

2. Plokhova V.I. (2014). Konstitutsionnye i mezhdunarodnye normy v UK RF [Constitutional and International Rules in the Criminal Code of the Russian Federation ]. Criminology Journal of Baikal National University of Economics and Law, (2), 96-104.

3. Postanovlenie Plenuma VS RF ot 27 iiunia 2013 g. № 21 "O primenenii sudami obshchei iurisdiktsii Konventsii o zashchite prav cheloveka $i$ osnovnykh svobod ot 4 noyabrial950 goda $i$ Protokolov k nei”; Postanovlenie Konstitutsionnogo Suda RF ot 5 fevralia 2007 g. i dr. [Resolution of the Plenum of the Supreme Court of the Russian Federation No. 21 dated June 27, 2013 "On application of the Convention for the Protection of Human Rights and Fundamental Freedoms by the court of general jurisdiction dated November 4, 1950 and the records to it"; Resolution of the Constitutional Court of the Russian Federation dated February 5, 2007, etc.]. Available at: http://www.supcourt.ru/ second.php

\section{Обоснование деликтного законодательства требованиями Конституции РФ}

В.И. Плохова

Алтайский государственный университет Россия, 656031, Барнаул, пр. Красноармейский, 81

В статье названы и кратко охарактеризованы конституционные требования к форме $и$ содержанию закона, ограничивающего права и свободы человека, в том числе деликтного; а также признаки правового закона, составляющие понятия верховенства права, его соотнотение с формальными и содержательными требованиями к закону.

Ключевые слова: правовой закон, верховенство права, предсказуемость, степень важности, содержание, форма.

Научная специальность: 12.00.00 - юридические науки. 